Sérgio Henrique Rodrigues da Silva

Crescimento econômico, volatilidade e sua interação: qual o papel do desenvolvimento financeiro?

Brasília

Março de 2016 

Sérgio Henrique Rodrigues da Silva

\title{
Crescimento econômico, volatilidade e sua interação: qual o papel do desenvolvimento financeiro?
}

\author{
Dissertação apresentada como requisito par- \\ cial para obtenção do título de Mestre pelo \\ Programa de Pós-Graduação em Economia do \\ Departamento de Economia da FACE/UnB.
}

\author{
Universidade de Brasília - UnB \\ Faculdade de Economia, Administração e Contabilidade \\ Departamento de Economia
}

Orientador: Prof. Dr. Daniel Oliveira Cajueiro

Brasília

Março de 2016 
Sérgio Henrique Rodrigues da Silva

Crescimento econômico, volatilidade e sua interação: qual o papel do desenvolvimento financeiro?/ Sérgio Henrique Rodrigues da Silva. - Brasília, Março de 2016-

45 p. : il. (algumas color.) ; $30 \mathrm{~cm}$.

Orientador: Prof. Dr. Daniel Oliveira Cajueiro

Dissertação (Mestrado) - Universidade de Brasília - UnB

Faculdade de Economia, Administração e Contabilidade

Departamento de Economia, Março de 2016.

1. Desenvolvimento financeiro. 2. Crescimento econômico. 3. Volatilidade. I. Oliveira Cajueiro, Daniel. II. Universidade de Brasília. III. Faculdade de Economia, Administração e Contabilidade. IV. Título 
À minha esposa Ivana 



\section{Agradecimentos}

Ao Banco Central do Brasil, instituição da qual faço parte e patrocinadora de minha participação neste curso; à Universidade de Brasília, pelos esforços em oferecer educação de qualidade; e à sociedade brasileira como um todo, espero retribuir esta oportunidade e aplicar os conhecimentos adquiridos em minhas atribuições como servidor público.

Aos professores das disciplinas que cursei, pelo empenho em disseminar seu conhecimento.

Ao meu orientador, professor Daniel Cajueiro, e ao professor Benjamin Tabak, pela participação e contribuição ao longo de toda a elaboração deste trabalho. Ao colega Dimas Fazio, pelos comentários e sugestões. Ao professor Eduardo Borges, pela participação na banca examinadora.

Aos colegas e amigos de curso, pelo companheirismo e colaboração mútua durante todo este período.

A meus pais, João e Ana Maria, pelo amor e incentivo aos estudos desde sempre.

À minha esposa Ivana, pelo amor, apoio, companheirismo e compreensão. 



\section{Resumo}

Este trabalho examina a relação entre o desenvolvimento financeiro e a interação entre o crescimento econômico e a sua volatilidade. É usada uma amostra de 52 países para o período 1980-2011, e a principal conclusão é que, em níveis moderados de profundidade financeira, a elevação desta aumenta a razão entre o crescimento médio e a volatilidade; porém, à medida que a profundidade financeira se eleva, esta relação se reverte, e o aumento da volatilidade ultrapassa o do crescimento econômico. Este resultado é obtido tanto no médio como no longo prazo; no entanto o pico da relação parece ser menor no médio prazo (entre $40 \%$ e $55 \%$ do Crédito Doméstico/PIB) do que no longo prazo (entre $75 \%$ e 99\%). Isto sugere que elevar o nível de Crédito Doméstico pode intensificar a volatilidade relativa no médio prazo, mas ainda assim pode elevar o crescimento relativo de longo prazo antes que o limiar de longo prazo seja atingido.

Palavras-chave: Desenvolvimento financeiro. Crescimento. Volatilidade. Não linearidade. 



\section{Abstract}

This work examines the relation between financial depth and the interaction of economic growth and its volatility. I use a sample of 52 countries for the period 1980-2011, and the main finding is that, at moderate levels of financial depth, further deepening increases the ratio of average growth to volatility; however, as financial depth gets higher, this relation reverts, and the raise in volatility overcomes that of economic growth. This result is obtained both in the medium- and long-run; however, the peak of the relation seems to be lower in the medium-run (around $40 \%$ to $55 \%$ of Domestic Credit/GDP) than in the long-run (around 75\% to 99\%). This suggests that increasing the level of Domestic Credit may intensify relative volatility in the medium-term, but still may raise relative long-term growth before the long-run threshold is achieved.

Keywords: Financial development. Growth. Volatility. Non-linearity. 



\section{Lista de ilustrações}

Figura 1 - GDP pc growth, selected countries . . . . . . . . . . . 35 



\section{Lista de tabelas}

Tabela 1 - Summary statistics - Cross-Sectional Data . . . . . . . . . . . 37

Tabela 2 - Summary statistics - Panel Data . . . . . . . . . . 37

Tabela 3 - Financial Growth Nexus - Cross-Sectional Specifications - $Z_{i}\left(\Delta \mathrm{GDP}_{p c}\right) \quad 38$

Tabela 4 - Financial Growth Nexus - Cross-Sectional Specifications - $\Delta$ GDP $_{p c}$. . 39

Tabela 5 - Financial Growth Nexus - Cross-Sectional Specifications - $\sigma_{i}\left(\Delta \mathrm{GDP}_{p c}\right) \quad 40$

Tabela 6 - Financial Growth Nexus - Panel Specifications - $Z_{i}\left(\Delta \mathrm{GDP}_{p c}\right) \ldots \ldots 4$

Tabela 7 - Financial Growth Nexus - Panel Specifications - $\Delta \mathrm{GDP}_{p c} \ldots \ldots$. . . . 42

Tabela 8 - Financial Growth Nexus - Panel Specifications $-\sigma_{i}\left(\Delta \mathrm{GDP}_{p c}\right) \ldots \ldots$ 



\section{Sumário}

Introdução . . . . . . . . . . . . . . . . 17

1 DADOS E METODOLOGIA . . . . . . . . . . . . 21

2 RESULTADOS EMPÍRICOS . . . . . . . . . . . . . . . . 23

2.1 Dados Cross-Section . . . . . . . . . . . . . . . . . . 23

$2.2 \quad$ Dados de Painel . . . . . . . . . . . . . . . . . . . . . . 24

2.3 Testes de robustez . . . . . . . . . . . . . . 26

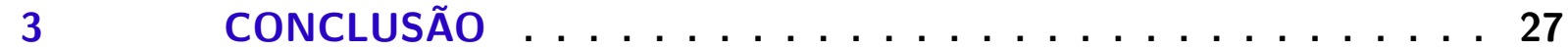

REFERÊNCIAS ........................ 29

$\begin{array}{ll}\text { APÊNDICES } & 33\end{array}$

APÊNDICE A-FIGURAS . . . . . . . . . . . 35

APÊNDICE B - TABELAS . . . . . . . . . . . 37

APÊNDICE C - FONTES DE DADOS . . . . . . . . . . 45 



\section{Introdução}

No início dos anos 2000, havia um crescente consenso de que as finanças ${ }^{1}$ tinham um papel substancial em promover o crescimento econômico. Basicamente, instituições financeiras alocam a poupança privada e pública entre firmas e indivíduos. Um melhor desenvolvimento financeiro levaria a alocações mais eficientes, e assim induziria o crescimento econômico. Apesar disso, a ideia de que esta relação não é tão simples e direta começou a ganhar força, especialmente após o início da crise financeira global. Qual é a influência do desenvolvimento financeiro no crescimento econômico? Será que as finanças lubrificam o motor do sistema econômico, ajudando a reduzir as flutuações do ciclo de negócios, ou elas elevam a variação do crescimento econômico ao redor de sua tendência?

Este trabalho examina a relação entre o desenvolvimento financeiro e a interação entre crescimento econômico e sua volatilidade. O principal resultado obtido é que, em níveis moderados de profundidade financeira ${ }^{2}$, a elevação desta aumenta a razão entre o crescimento médio e a volatilidade; porém, à medida que a profundidade financeira se eleva, esta relação se reverte, e o aumento da volatilidade ultrapassa o do crescimento econômico.

Este trabalho se relaciona com quatro corpos de literatura conectados. A literatura preliminar propôs que sistemas financeiros bem desenvolvidos são associados com crescimento econômico mais rápido, mas ainda não possuia as ferramentas para avaliar apropriadamente esta proposição ${ }^{3}$. Levine (2005) resume este argumento em cinco funções principais dos sistemas financeiros: produzir informações sobre oportunidades de investimento; monitorar os empreendimentos que recebem recursos financeiros; ajudar no gerenciamento de risco; agregar recursos de poupança, permitindo a capitalização de projetos de investimento de larga escala; e facilitar a troca de bens e serviços.

O primeiro estudo empírico tentando avaliar a relação causal do desenvolvimento financeiro sobre o crescimento econômico foi King e Levine $(1993)^{4}$. Eles empregaram três medidas principais do desenvolvimento dos intermediários financeiros e usaram, além do crescimento do PIB per capita, o crescimento do capital per capita e o crescimento da

1 Neste trabalho, os termos "finanças" e "desenvolvimento financeiro" são utilizados como sinônimos.

2 Cihák et al. (2013) utilizam quatro dimensões para classificar o nível de desenvolvimento financeiro de um país: profundidade financeira (que mede o tamanho das instituições e mercados financeiros), o grau de acesso da população ao sistema financeiro, e eficiência dos sistemas financeiros no provimento de seus serviços, e a estabilidade do sistema financeiro. Este trabalho se concentra na dimensão profundidade financeira, devido a limitações na disponibilidade de dados (em termos de amostra temporal e amostra de países) relativos às demais dimensões.

3 Na verdade, esta ideia existe desde o final do século XIX, por exemplo nos trabalhos de Bagehot (1873), Schumpeter (1934) e Gurley e Shaw (1955).

4 Estudos anteriores encontraram uma correlação positiva entre finanças e crescimento, como Goldsmith (1969), mas não estabeleceram uma relação causal. 
produtividade como variáveis dependentes, para avaliar os canais através dos quais as finanças influenciam o crescimento econômico. Seus resultados indicaram que havia uma relação positiva entre os indicadores de desenvolvimento financeiro e os indicadores de crescimento, e que o desenvolvimento financeiro inicial era um bom previsor para o crescimento de longo prazo subsequente. Trabalhos relacionados, como Levine e Zervos (1998), expandiram o escopo das medidas de desenvolvimento financeiro, incluindo indicadores de desenvolvimento dos mercados de ações, e encontraram resultados similares.

A segunda vertente da literatura sustenta uma relação causal positiva do desenvolvimento financeiro no crescimento econômico. Os trabalhos mais influentes foram Levine, Loayza e Beck (2000) e Beck, Levine e Loayza (2000), que usaram regressões cross-section com variáveis instrumentais e métodos de painel dinâmico GMM para reavaliar o trabalho de King e Levine (1993). A variável instrumental usada para o desenvolvimento financeiro foi a origem legal do país, seguindo La Porta et al. (1998). Eles constaram que o componente exógeno do desenvolvimento financeiro tem um impacto positivo no crescimento do PIB e da produtividade, mas não na acumulação de capital e na taxa de poupança.

Aghion, Howitt e Mayer-Foulkes (2005) tiveram uma abordagem diferente para analisar o nexo finanças-crescimento. A maioria dos estudos (ao menos implicitamente) assumem que o desenvolvimento financeiro pode afetar a taxa de crescimento de estado esacionário; no entando, Aghion, Howitt e Mayer-Foulkes (2005) sugeriram que o desenvolvimento financeiro pode acelerar a convergência para o estado estacionário sem alterar o próprio crescimento de estado estacionário. Para checar isto, eles usaram uma regressão cross-section similar a Levine, Loayza e Beck (2000), adicionando um termo de interação entre o nível inicial do PIB per capita relativo e os indicadores de desenvolvimento financeiro. Os resultados foram de acordo com sua hipótese.

Enquanto isso, alguns estudos começaram a propor que o impacto das finanças sobre o crescimento poderia variar de acordo com o nível de desenvolvimento financeiro. Rioja e Valev (2004) reproduziram o trabalho de Levine, Loayza e Beck (2000), dividindo a amostra em três regiões: baixo, médio e alto desenvolvimento financeiro. Dessa maneira, eles perceberam que o impacto da elevação do desenvolvimento financeiro sobre o crescimento era pequeno na região de baixo desenvolvimento financeiro, mas era forte na região média. Loayza e Rancière (2006) tentaram ligar a literatura sobre desenvolvimento financeiro coma literatura sobre crises financeiras ${ }^{5}$, a qual afirma que indicadores de crédito podem ser usados como previsores de crises, e dessa forma ter uma influência negativa sobre o crescimento econômico. Eles utilizaram um método de Pooled Mean Group e dados de painel para separar as respostas de longo e curto prazo do crescimento econômico ao crédito privado, e confirmaram que esta relação é positiva no longo prazo; apesar disso, o oposto ocorre no curto prazo, de forma que o desenvolvimento financeiro pode estar

$5 \quad$ Como Kaminsky e Reinhart (1999). 
associado com volatilidade financeira e crises.

Depois disso, vários trabalhos começaram a explorar uma possível relação não monotônica entre finanças e crescimento, originando a terceira linha de trabalho principal relacionada. Cecchetti e Kharroubi (2012) empregaram um método de MQO agrupados e variáveis de desenvolvimento financeiro quadráticas, e verificaram que o crescimento do PIB por trabalhador pode ser expresso como uma função do desenvolvimento financeiro em forma de U invertido, com pico de cerca de $100 \%$ do PIB para crédito privado e $90 \%$ para crédito bancário. Law e Singh (2014) aplicaram uma regressão de painel dinâmico com limiar para testar a existência de um limiar de desenvolvimento financeiro, com efeitos diferentes sobre o crescimento econômico abaixo e acima dele. Para o crédito privado, eles observaram um limiar de aproximadamente $88 \%$ do PIB, e uma relação tipo $\mathrm{V}$ invertido, de forma que um desenvolvimento financeiro acima deste nível prejudicaria o crescimento econômico. Arcand, Berkes e Panizza (2015) utilizaram estimações semiparamétricas e painel dinâmico GMM com termo quadrático do crédito privado, e obtiveram resultados similares, também com pico de cerca de 100\% do PIB. Sahay et al. (2015) criaram um índice de desenvolvimento financeiro, compreendendo tando instituições como mercados financeiros, e três dimensões do desenvolvimento financeiro: profundidade, acesso e eficiência. Usando painel dinâmico GMM e o termo quadrático do índice, eles alcançaram resultados análogos, de modo que um alto índice de desenvolvimento financeiro atrapalha o crescimento econômico.

Finalmente, a quarta linha de literatura estudou o impacto do desenvolvimento financeiro na volatilidade do crescimento econômico, medida pelo desvio padrão do crescimento do PIB per capita. Easterly, Islam e Stiglitz (2001) encontrou uma fraca evidência de um efeito em forma de $\mathrm{U}$ do crédito privado sobre a volatilidade do crescimento. No entando, a literatura subsequente propôs majoritariamente uma relação linear entre desenvolvimento financeiro e volatilidade, e encontrou evidências de uma relação negativa. Beck, Lundberg e Majnoni (2006) tentaram avaliar como o desenvolvimento financeiro influencia o impacto de volatilidades real e monetária sobre a volatilidade do crescimento. Eles verificaram que um crédito privado mais alto pode reduzir e aumentar os efeitos das volatilidades real e monetária, respectivamente, especialmente se os mercados de ações forem pouco desenvolvidos. Além disso, Beck, Degryse e Kneer (2014) usaram uma nova medida de desenvolvimento financeiro para separar os efeitos das atividades dos sistemas finaceiros de intermediação e não-intermediação (tais como "criação de mercados", serviços de consultoria e seguros, entre outros) sobre o crescimento econômico e a volatilidade do crescimento. O principal resultado que encontraram foi que a intermediação financeira eleva o crescimento e reduz a volatilidade no longo prazo, mas estes efeitos se tornam mais fracos quando se considera um horizonte temporal mais curto e mais recente; no entanto, atividades de não-intermediação não afetam o crescimento nem a volatilidade no longo prazo, e podem elevar a volatilidade no médio prazo. 
Este trabalho extende a literatura prévia levando em consideração uma relação não linear do desenvolvimento financeiro sobre a volatilidade do crescimento, e apresenta evidência robusta de que existe da mesma maneira "too much finance" neste caso. Além disso, é empregada uma nova medida para avaliar a interação entre o crescimento econômico e a sua volatilidade, e também é encontrada uma relação não linear entre o desenvolvimento financeiro e esta variável. Isto significa que, à medida que as finanças se aprofundam, a volatilidade do crescimento irá crescer mais rápido que o próprio crescimento médio.

O restante deste trabalho é organizado da seguinte maneira: o Capítulo 1 (em inglês) discute os dados e métodos empregado no modelo; o Capítulo 2 (em inglês) apresenta os resultados empíricos; e o Capítulo 3 apresenta as conclusões. 


\section{Dados e Metodologia}

In this work I use two dependent variables traditionally used to measure the increase of a country's welfare and its volatility, and I propose a new indicator to assess this last dimension. The first two variables are average real GDP per capita growth $\left(\Delta \mathrm{GDP}_{p c}\right.$ or $\left.\Delta\right)$ and its standard deviation $\left(\sigma\left(\Delta \mathrm{GDP}_{p c}\right)\right.$ or $\left.\sigma\right)$. However, it's widely known that standard deviation is not adequate to measure the relative dispersion of a variable. To deal with that, I introduce the indicator $Z\left(\Delta \mathrm{GDP}_{p c}\right)$ or simply $Z$, defined as the inverse hyperbolic sine transformation ${ }^{1}$ of $\Delta$ divided by $\sigma$, for a given time period. That way, higher values of $Z$ imply that the country is attaining higher levels of growth with lower growth volatility ${ }^{2}$.

To illustrate the relevance of variable $Z$, Figure 1 presents the evolution over time of annual $\Delta$ in Estonia, Korea, Slovakia and Vietnam. These four countries have, in the period considered, an average $\Delta$ around $5.3 \%$. Despite that, their volatility is considerably different, ranging from $1.1 \%$ in Vietnam to $6.4 \%$ in Estonia, resulting $Z$ values of 0.76 and 2.33 , respectively. Note that a high $Z$ implies that the country is less prone to recessions; for instance, Vietnam only had positive $\Delta \mathrm{s}$ in this period.

Insert Figure 1 here

I use as main independent variable of interest a standard measure of financial depth (FD), domestic credit by banks (Dom. Credit). This variable refers to the log of the ratio of outstanding credit provided by banks to the private sector by the GDP ${ }^{3}$. I follow the finance-growth nexus literature, using the country's legal origin as instrumental variable for the FD indicator ${ }^{4}$.

The control variables are also chosen according to this literature, and are divided in two groups: the narrow one includes the log of GDP per capita from the first year of period (Initial $\mathrm{GDP}_{p c, 0}$ ), and the log of one plus the average years of schooling of the adult population (Years of Schl.); the wide group includes both variables from the first group, and additionally the log of government final consumption expenditure relative to GDP (Govrmnt. Consumption), the log of the sum of imports and exports of goods and services over the GDP (Ecnmy. Openness), and consumer inflation (Cons. Price Index).

$1 \quad$ The inverse hyperbolic sine transformation of variable $\mathrm{x}$ is defined as $\ln \left(x+\left(x^{2}+1\right)^{1 / 2}\right)$. We use this transformation instead of the logarithmic one because it allows negative or zero values of the transformed variable, maintaining approximately the same marginal effect of the log transformation.

2 When average growth is negative, low volatility (and thus low values of $Z$ ) imply that the chance of the country attaining positive growth was low.

3 It may include credit to public enterprises.

4 I use dummy variables that represent the country's legal origin: English, French, German, or Scandinavian. 
The sample is composed of 52 countries with data for the period 1980 to 2011. Two datasets are built based on this sample: a cross-sectional one, with data averaged by country over the whole sample period; and a panel dataset, with data averaged by country over 5-year non-overlapping intervals. Tables 1 and 2 present summary statistics of main variables for the cross-section e panel datasets, respectively.

Insert Table 1 here

Insert Table 2 here

For the cross-sectional database, the econometric methods employed are standard OLS and instrumental variables OLS (IV); and for the panel dataset, we employ pooled OLS (POLS), a fixed effects specification (FE), and the dynamic panel Arellano-Bond estimator $(\mathrm{AB})$, where the instruments are the lags of the explanatory variables (in levels and differences $)^{5}$. The main motivation for the use of $\mathrm{AB}$ is the presence of independent variables that may not be strictly exogenous, such as financial development variables themselves ${ }^{6}$, and to present a dynamic specification avoiding "dynamic panel bias" For all specifications, I include a squared term of the financial depth variable, to allow non-monotonic effects. Time fixed effects are included in all panel specifications.

$5 \quad$ In this last case, I also include excluded instruments that reflect the country's legal origin (English, French, German, or Scandinavian).

6 See the discussion in the Introduction on the causal relation between financial development and growth.

7 Caused by correlation between the lagged dependent variable and the fixed effects in the error term. 


\section{Resultados Empíricos}

\subsection{Dados Cross-Section}

Tables 3 to 5 present results of the cross-section regressions for $Z, \Delta$ and $\sigma$ as dependent variables. In all tables, columns [1] to [4] and [5] to [8] present the results using Dom. Credit and Priv. Credit as main independent variable, respectively; moreover, columns [1], [3], [5] and [7] present the results employing the narrow group of control variables, while columns [2], [4], [6] and [8] employ the wide group; finally, columns [1], [2], [5] and [6] present the results of the standard OLS specification, while columns [3], [4], [7], [8] present the results of the IV specification.

Regarding $Z$, the FD variable linear and squared terms are statistically significant in all specifications, as shown in Table 3. Linear terms always have a positive coefficient, whereas the squared terms' coefficients are negative. That way, the relation of FD and volatility is hump-shaped, with a ceteris paribus positive marginal effect on $Z$ for low values of FD, but this effect becomes negative as FD increases. All other things equal, for a country with the lowest level of average Dom. Credit in the sample (2.8), a $1 \%$ increase in Dom. Credit would lead to around $1 \%$ increase in $Z$; however, for the highest level of Dom. Credit (5.0), the same increase in this variable would lead to a decrease between $0.2 \%$ and $0.5 \%$ in $Z$. Moreover, the estimated maximum point after which Dom. Credit starts exerting a negative impact on $Z$ is around the original variable value of $75 \%$ (with respect to the OLS wide control group specification) ${ }^{1}$. The $90 \%$ confidence interval (CI) for this critical point ranges from $48 \%$ to $117 \%$; 21 of the 52 observations have Dom. Credit below the lower bound of this interval, thus are in the significant positive marginal effect region, and 3 are above the upper bound, and have a significant negative marginal effect. Note that the estimated critical points when the wide control group is employed are smaller than the estimated using the narrow group.

\section{Insert Table 3 here}

It's also noteworthy that the coefficients for the exogenous component of FD considerably higher than the standard OLS ones. The results also indicate that education has a positive impact on $Z$, whereas the effect of initial GDP is negative, indicating that high income countries may have lower long run growth rates and/or higher growth volatility (the next tables will try to untie these effects). Government size and inflation

$\overline{1}$ The critical points analysis always consider the variable values before transformation. 
impacts are not significant, and the OLS specifications point a negative effect of trade openness on volatility.

I do not find a significant long-run relation of the linear and squared terms of FD on growth (Table 4). However, in an unreported specification without the squared term ${ }^{2}$, I find that the linear term's coefficient is positive and significant, around 0.01 for the OLS estimators and around 0.03 for the IV ones. This means that, considering the OLS results, a $1 \%$ increase in Dom. Credit would lead to around 0.01 p.p. increase in $\Delta$. Education has a positive impact on growth, while the effect of initial GDP is negative, as expected by the convergence hypothesis. Government consumption seems to have a small positive influence on long-run growth, but generally the other control variables do not have a significant effect.

\section{Insert Table 4 here}

Finally, when I use the wide control group, $\sigma$ is significantly affected by both FD variable's linear and squared terms, whose coefficients are negative and positive, respectively (Table 5), implying a valley-shaped relation, with minima very close to the maxima achieved in the $Z$ regressions. This suggests, along with the results of last paragraph, that FD affects $Z$ both through its effect on growth and its standard deviation. It's also noticeable that government size always has a positive and significant coefficient. Openness exhibits a positive and significant impact on the OLS specifications, and inflation also presents this characteristic on the IV specifications.

Insert Table 5 here

\subsection{Dados de Painel}

Tables 6 to 8 present results of the panel data regressions for $Z, \Delta$ and $\sigma$ as dependent variables. In all tables, columns [1] to [6] and [7] to [12] present the results using Dom. Credit and Priv. Credit as main independent variable, respectively; moreover, columns [1], [3], [5], [7], [9] and [11] present the results employing the narrow group of control variables, while columns [2], [4], [6], [8], [10] and [12] employ the wide group; finally, columns [1], [2], [7] and [8] present the results of the pooled OLS specification, columns [3], [4], [9] and [10] present the results of the fixed effects specification, and columns [5], [6], [11] and [12] present the results of the dynamic panel Arellano-Bond estimator.

We can see on Table 6 that, for variable $Z$, the linear and squared terms of the FD variables are significant and have positive and negative coefficients, respectively, in all

$\overline{2}$ Regression results are available upon request 
panel data specifications, as in the cross-section specifications. Additionally, the absolute value of the FD variable coefficients in the POLS specification are greater than those of the OLS specification, suggesting that the impact of financial depth on volatility is greater in the medium-run than in the long-run. Furthermore, when we add country fixed effects, the estimated coefficients are larger (in absolute value) then those of the POLS, and the same also happens when we employ the dynamic panel estimator. In the POLS specifications, the estimated maximum value of $Z$ is achieved for values of Dom. Credit around 53\%; when using $\mathrm{FE}$ and $\mathrm{AB}$, these values are lower: about $41 \%$ and $43 \%$, respectively. The 90\% CIs for the critical points, using the wide control group and the POLS, FE and AB estimators, are $45 \%-59 \%, 30 \%-54 \%$ and $29 \%-58 \%$; the number of observations below the CI lower bound are 142, 87 and 80; and above the CI upper bound are 150, 163 and 152, respectively.

The data also support a negative and significant effect of inflation on medium term volatility. The POLS specifications endorse a positive impact of education and a negative impact of government spending. Initial GDP and openness have positive and negative coefficients, respectively, but both mostly are not significant. The lagged $Z$ term does not have a significant impact on the AB specifications.

Insert Table 6 here

The panel specifications indicate a hump-shaped effect of FD on medium-run growth (except the AB specifications), differently from the results obtained in the crosscountry specifications (Table 7). The estimated peak of the relation is around $59 \%$ and $44 \%$ in POLS and FE, respectively. Theses values are close to the ones obtained in the $Z$ regressions. Government spending, inflation and openness have negative and significant effects, whereas initial GDP has a positive coefficient. Education only has a significant impact in the $\mathrm{AB}$ specifications, which also reveal a positive influence from lagged GDP growth.

Insert Table 7 here

Data on Table 8 also support a valley-shaped medium term relation between FD and growth standard deviation (again, except the AB specifications). Comparing to the growth regressions considered in last paragraph, the $\sigma$ regressions have estimated valley on somewhat higher values of the FD variable, around $65 \%$ and $54 \%$, in POLS and FE specifications, respectively. Initial GDP and Government Consumption seem to increase volatility, while education reduces it, in the POLS specification. All the other control variables do not present significant effects. 


\subsection{Testes de robustez}

I performed robustness tests to assess the responsiveness of the results to using a different measure of financial depth and alternative time samples. The first test was to replace Dom. Credit by private credit by banks and other financial institutions (Priv. Credit). These variables represent different concepts of credit, and one is not a subset of the other: as mentioned before, Dom. Credit refer to credit provided by banks to the private sector, including credit to public enterprises; and Priv. Credit refers to credit provided by banks and other financial institutions to the private sector. All results obtained using Priv. Credit are very similar to the main results. For example, the estimated critical points for the cross-section OLS Priv. Credit specifications with dependent variable $Z$ are around $71 \%$ and $98 \%$, and the Panel data peaks for POLS, FE and AB are achieved around 50\%, $34 \%$ and $35 \%$, respectively.

The second set of robustness tests consisted of using alternative time samples. For the cross-sectional data, I used the alternative period of 1990-2011, again reaching similar results. For the Panel data, I changed the starting year from 1981 to 1984, so the 5-year intervals in each time sample were different. The outcomes were also consistent with the main results.

I conducted tests using interaction terms between the financial development variables (both linear and squared) and the control variables, but the estimated coefficients obtained were never individually significant. Finally, for the PD specifications I test whether the estimated coefficient of the lagged dependent variable using the AB estimator lies between the ones estimated by dynamic POLS (upward biased) and FE (downward biased) specifications, as described by Roodman $(2009)^{3}$. The only specification that did not match this criterion was the $\Delta \mathrm{PD}$ regression using the wide control group, for which the estimated AB coefficient for the lagged term (0.391) was slightly small than the POLS one (0.382).

3 Conditional on the true parameter being positive. 


\section{Conclusão}

Neste trabalho, eu avaliei o impacto do desenvolvimento financeiro sobre a interação entre o crescimento econômico e sua volatilidade. Eu introduzi uma nova variável, $Z$, que mede a razão entre o crescimento médio e sua volatilidade. Os resultados são compatíveis com a literatura "too much finance". O desenvolvimento financeiro eleva $Z$ até certo ponto, e então começa a reduzí-lo, tanto no médio como no longo prazo. Isto significa que, mesmo que o desenvolvimento financeiro acelere o crescimento econômico, ele irá simultânea e mais que proporcionalmente elevar a volatilidade do crescimento.

A principal diferença entre os resultados de longo e médio prazos é que não foi encontrada uma relação quadrática do desenvolvimento financeiro sobre o crescimento econômico no longo prazo, mas os dados dão suporte a esta relação no médio prazo. Isto significa que, no médio prazo, as finanças começam tanto a reduzir o crescimento como a elevar a volatilidade depois que um limiar é ultrapassado. Os limiares estimados nas especificações de dados de painel (DP) também são um tanto menores que aqueles obtidos nas especificações cross-section (CS): para $Z$, por exemplo, os limiares estimados estão em torno de $40 \%$ a $55 \%$ para DP, e em cerca de $75 \%$ a $99 \%$ para CS. Isto sugere que a elevação do nível de Crédito Doméstico pode intensificar a volatilidade relativa no médio prazo, mas ainda assim pode elevar o crescimento relativo de longo prazo antes que o limiar de longo prazo seja atingido. 



\section{Referências}

AGHION, P.; HOWITT, P.; MAYER-FOULKES, D. The effect of financial development on convergence: Theory and evidence. The Quarterly Journal of Economics, v. 120, n. 1, p. 173-222, February 2005. Disponível em: <http: //qje.oxfordjournals.org/content/120/1/173.abstract>. Citado na página 18.

ARCAND, J. L.; BERKES, E.; PANIZZA, U. Too much finance? Journal of Economic Growth, Springer US, v. 20, n. 2, p. 105-148, 2015. ISSN 1381-4338. Disponível em: <http://dx.doi.org/10.1007/s10887-015-9115-2> Citado na página 19.

BAGEHOT, W. Lombard Street: A description of the money market. 3. ed. London: Henry S. King \& Co., 1873. Citado na página 17.

BECK, T.; DEGRYSE, H.; KNEER, C. Is more finance better? disentangling intermediation and size effects of financial systems. Journal of Financial Stability, v. 10, n. 0, p. 50 - 64, 2014. ISSN 1572-3089. Disponível em: <http://www.sciencedirect.com/ science/article/pii/S1572308913000235>. Citado na página 19.

BECK, T.; LEVINE, R.; LOAYZA, N. Finance and the sources of growth. Journal of Financial Economics, v. 58, n. 1-2, p. 261 - 300, 2000. ISSN 0304-405X. Disponível em: <http://www.sciencedirect.com/science/article/pii/S0304405X00000726>. Citado na página 18.

BECK, T.; LUNDBERG, M.; MAJNONI, G. Financial intermediary development and growth volatility: Do intermediaries dampen or magnify shocks? Journal of International Money and Finance, v. 25, n. 7, p. 1146 - 1167, 2006. ISSN 0261-5606. Disponível em: <http://www.sciencedirect.com/science/article/pii/S0261560606000763>. Citado na página 19.

CECCHETTI, S. G.; KHARROUBI, E. Reassessing the impact of finance on growth. Bank for International Settlements, 2012. Disponível em: < http: //www.bis.org/publ/work381.htm>. Citado na página 19.

CIHÁK, M. et al. Financial development in 205 economies, 1960 to 2010. The Journal of Financial Perspectives, EY Global Financial Services Institute, v. 1, n. 2, p. 17-35, July 2013. Disponível em: <https://www.gfsi.ey.com/the-journal-x.php?pid=4\&id=23> . Citado na página 17.

EASTERLY, W.; ISLAM, R.; STIGLITZ, J. E. Annual world bank conference on development economics 2000. In: The World Bank, 2001. cap. Shaken and Stirred: Explaining Growth Volatility, p. 191-211. Disponível em: <http: //go.worldbank.org/M8ET570PL0>. Citado na página 19.

GOLDSMITH, R. Financial structure and economic development. New Haven: Yale University Press, 1969. Citado na página 17.

GURLEY, J. G.; SHAW, E. S. Financial aspects of economic development. The American Economic Review, v. 45, n. 4, p. 515-538, September 1955. Disponível em: <http://www.jstor.org/stable/1811632>. Citado na página 17. 
KAMINSKY, G. L.; REINHART, C. M. The twin crises: The causes of banking and balance-of-payments problems. American Economic Review, v. 89, n. 3, p. 473-500, June 1999. Disponível em: <https://www.aeaweb.org/articles.php?doi=10.1257/aer.89.3.473>. Citado na página 18.

KING, R. G.; LEVINE, R. Finance and growth: Schumpeter might be right. The Quarterly Journal of Economics, v. 108, n. 3, p. 717-737, 1993. Disponível em: $<$ http://qje.oxfordjournals.org/content/108/3/717.abstract>. Citado 2 vezes nas páginas 17 e 18.

LA PORTA, R. et al. Law and finance. Journal of Political Economy, v. 106, n. 6, p. 11131155, December 1998. Disponível em: <http://www.jstor.org/stable/10.1086/250042>. Citado na página 18.

LAW, S. H.; SINGH, N. Does too much finance harm economic growth? Journal of Banking $\& 6$ Finance, v. 41, n. 0, p. 36 - 44, 2014. ISSN 0378-4266. Disponível em: < http://www.sciencedirect.com/science/article/pii/S0378426613004925>. Citado na página 19.

LEVINE, R. Chapter 12 finance and growth: Theory and evidence. In: AGHION, P.; DURLAUF, S. N. (Ed.). Handbook of Economic Growth. Elsevier, 2005, (Handbook of Economic Growth, v. 1, Part A). p. 865 - 934. Disponível em: <http://www.sciencedirect.com/science/article/pii/S1574068405010129>. Citado na página 17.

LEVINE, R.; LOAYZA, N.; BECK, T. Financial intermediation and growth: Causality and causes. Journal of Monetary Economics, v. 46, n. 1, p. 31 - 77, 2000. ISSN 0304-3932. Disponível em: <http://www.sciencedirect.com/science/article/pii/S0304393200000179>. Citado na página 18.

LEVINE, R.; ZERVOS, S. Stock markets, banks, and economic growth. The American Economic Review, American Economic Association, v. 88, n. 3, p. pp. 537-558, June 1998. ISSN 00028282. Disponível em: <http://www.jstor.org/stable/116848>. Citado na página 18.

LOAYZA, N. V.; RANCIÈRE, R. Financial development, financial fragility, and growth. Journal of Money, Credit, and Banking, JSTOR, v. 38, n. 4, p. 1051-1076, June 2006. Disponível em: <http://romainranciere.com/research/jmcb.pdf > . Citado na página 18.

RIOJA, F.; VALEV, N. Does one size fit all?: a reexamination of the finance and growth relationship. Journal of Development Economics, v. 74, n. 2, p. 429 - 447, August 2004. ISSN 0304-3878. Disponível em: <http://www.sciencedirect.com/science/article/pii/ S0304387804000227>. Citado na página 18.

ROODMAN, D. How to do xtabond2: An introduction to difference and system gmm in stata. Stata Journal, Stata Press, College Station, TX, v. 9, n. 1, p. 86-136(51), 2009. Disponível em: <http://www.stata-journal.com/article.html?article=st0159>. Citado na página 26.

SAHAY, R. et al. Rethinking Financial Deepening: Stability and Growth in Emerging Markets. Washington: International Monetary Fund, 2015. (IMF Staff Discussion Note, 15/08). Disponível em: <http://www.imf.org/external/pubs/cat/longres.aspx?sk=42868>. Citado na página 19. 
SCHUMPETER, J. A. The theory of economic development. Cambridge, MA: Harvard University Press, 1934. Citado na página 17. 

Apêndices 



\section{APÊNDICE A - Figuras}

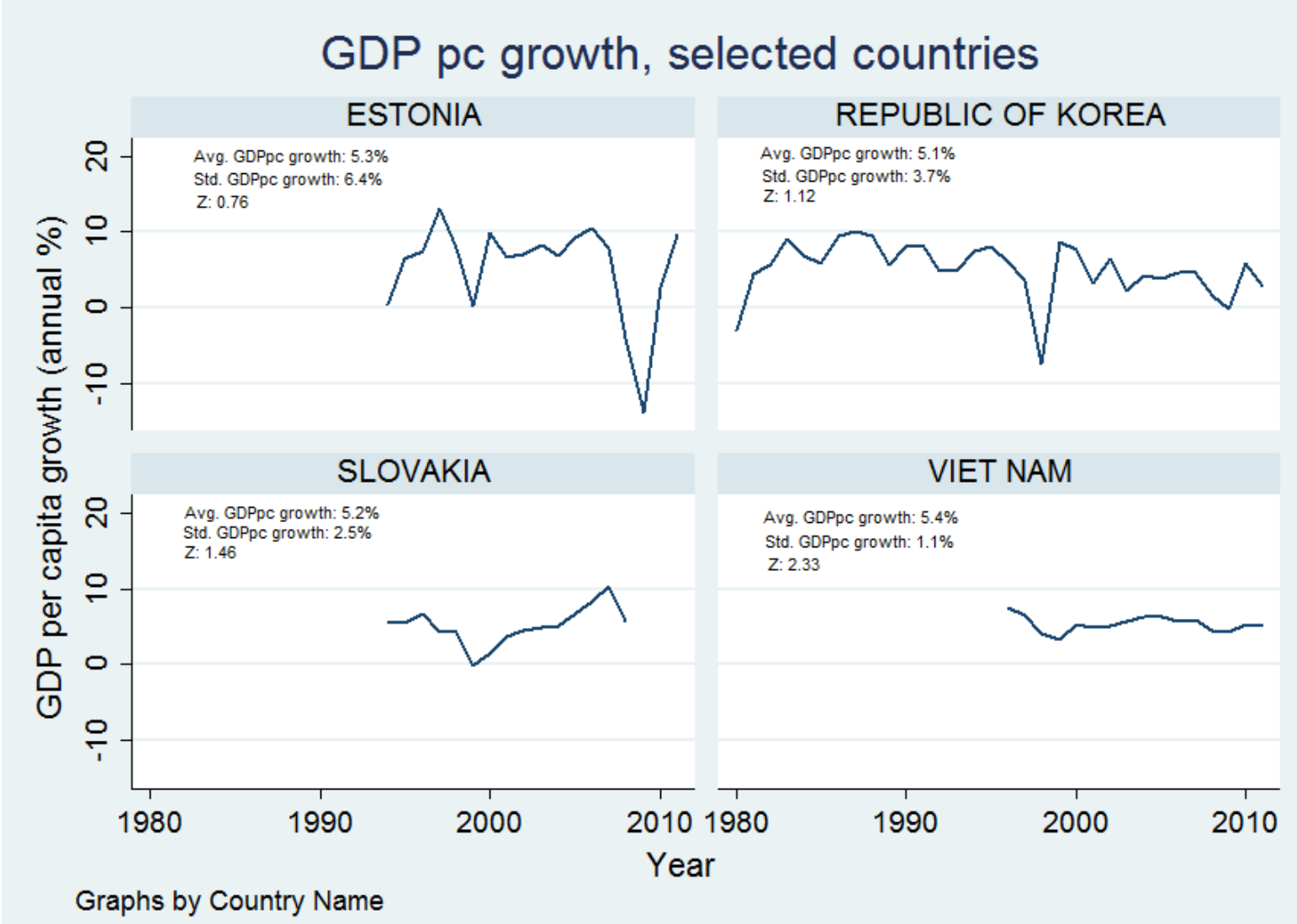

Figura 1 - GDP pc growth, selected countries 



\section{APÊNDICE B - Tabelas}

Tabela 1 - Summary statistics - Cross-Sectional Data

\begin{tabular}{lcccc}
\hline \multicolumn{1}{c}{ Variable } & Mean & Std. Dev. & Min. & Max. \\
\hline$\Delta \mathrm{GDP}_{p c, i}$ & 0.023 & 0.016 & -0.005 & 0.086 \\
$\sigma_{i}\left(\Delta \mathrm{GDP}_{p c, i}\right)$ & 0.989 & 0.428 & 0.059 & 1.872 \\
$Z\left(\Delta \mathrm{GDP}_{p c}\right)$ & 0.765 & 0.46 & -0.095 & 2.326 \\
Dom. Credit $_{i}$ & 4 & 0.593 & 2.779 & 5.01 \\
Priv. Credit $_{i}$ & 4.035 & 0.623 & 2.772 & 5.18 \\
Ecnmy Openness $_{i}$ & 4.146 & 0.533 & 3.019 & 5.46 \\
Cons. Price Index $_{i}$ & 0.173 & 0.371 & 0.011 & 1.682 \\
Years of Schl $_{i}$ & 1.262 & 0.339 & 0.629 & 1.839 \\
Govrmnt Consumption $_{i}$ & 2.767 & 0.347 & 1.619 & 3.294 \\
Initial GDP $_{p c, i 0}$ & 8.709 & 1.519 & 5.675 & 10.624 \\
\multicolumn{1}{c}{$\mathrm{N}$} & \multicolumn{2}{c}{52} & & \\
\hline
\end{tabular}

Tabela 2 - Summary statistics - Panel Data

\begin{tabular}{lcccc}
\hline \hline \multicolumn{1}{c}{ Variable } & Mean & Std. Dev. & Min. & Max. \\
\hline$\Delta \mathrm{GDP}_{p c, i}$ & 0.022 & 0.025 & -0.133 & 0.103 \\
$\sigma_{i}\left(\Delta \mathrm{GDP}_{p c, i}\right)$ & 0.536 & 0.797 & -2.121 & 2.362 \\
$Z\left(\Delta \mathrm{GDP}_{p c}\right)$ & 1.074 & 0.997 & -3.599 & 4.468 \\
Dom. Credit $_{i}$ & 3.96 & 0.715 & 2.131 & 5.365 \\
Priv. Credit $_{i}$ & 4.002 & 0.745 & 1.922 & 5.387 \\
Ecnmy Openness $_{i}$ & 4.115 & 0.564 & 2.568 & 5.764 \\
Cons. Price Index $_{i}$ & 0.127 & 0.347 & -0.012 & 3.225 \\
Years of Schl $_{i}$ & 1.251 & 0.386 & 0.329 & 2.067 \\
Govrmnt Consumption $_{i}$ & 2.763 & 0.351 & 1.514 & 3.504 \\
Initial GDP $_{p c, i 0}$ & 8.989 & 1.498 & 5.675 & 11.301 \\
\multicolumn{1}{c}{$\mathrm{N}$} & \multicolumn{3}{c}{335} \\
\hline
\end{tabular}




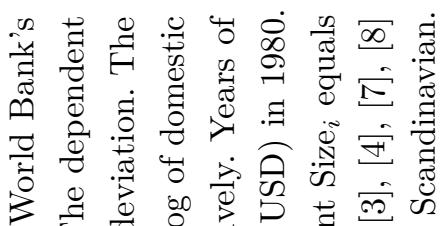

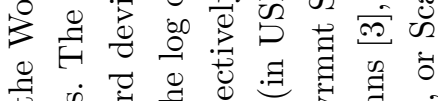

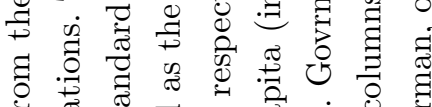

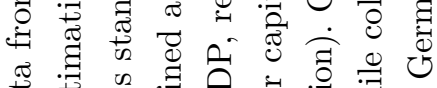

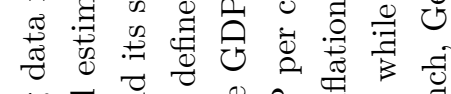

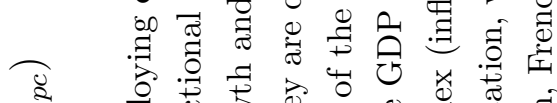

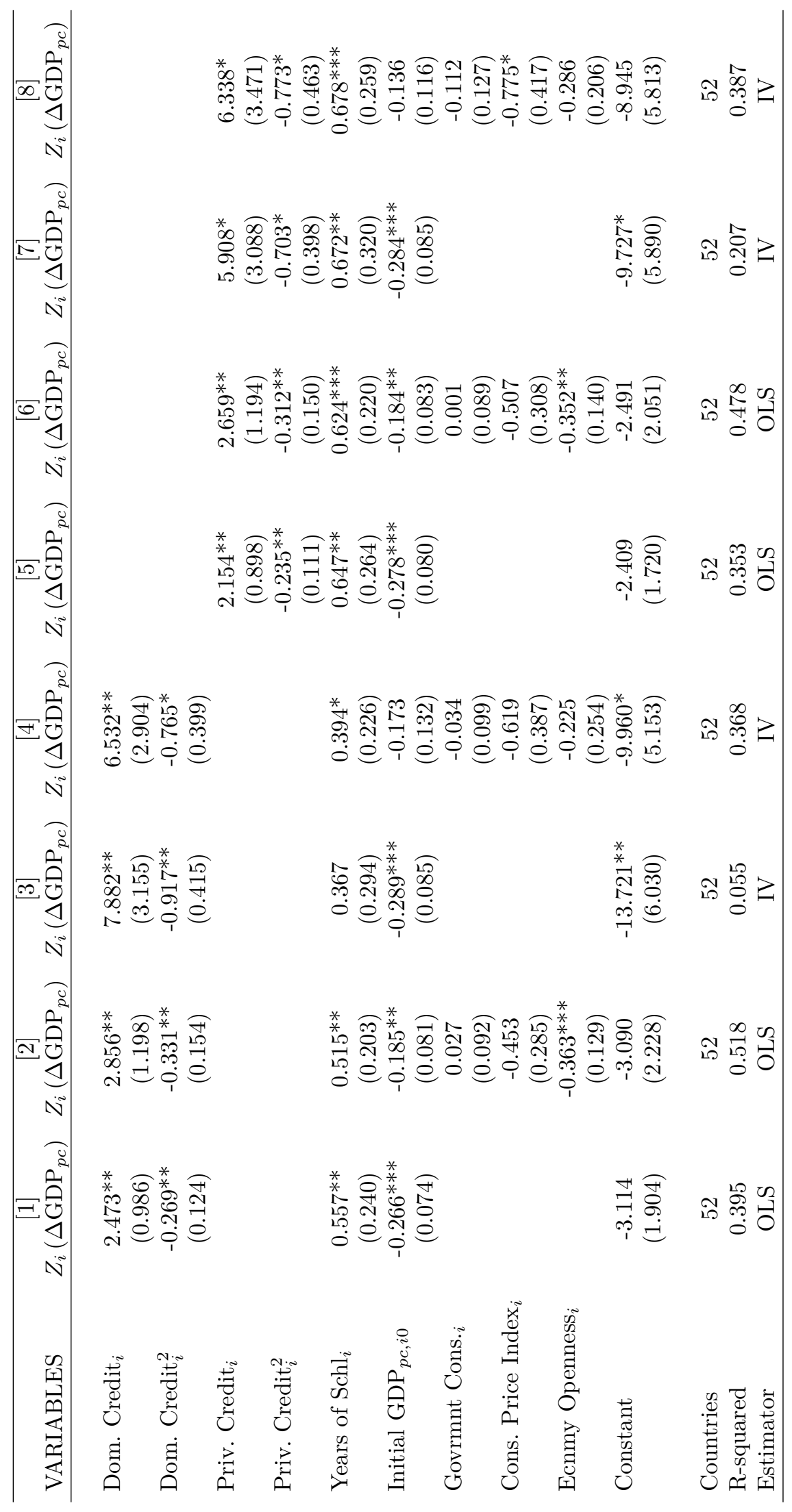

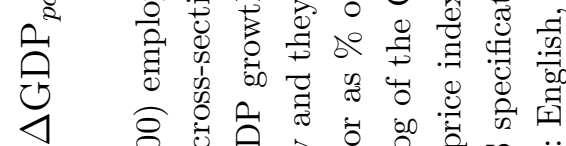

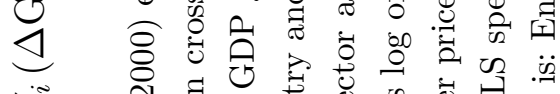
N

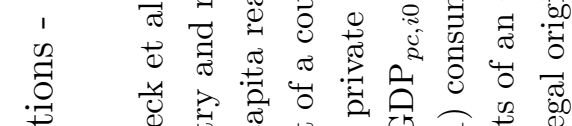

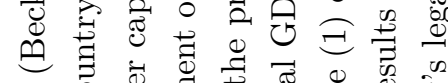

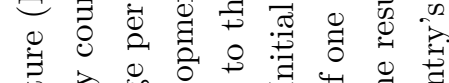

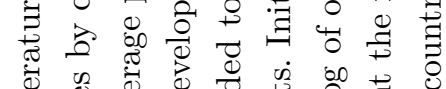

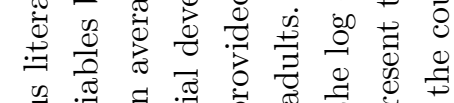

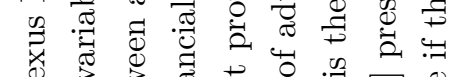

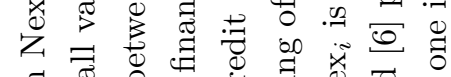

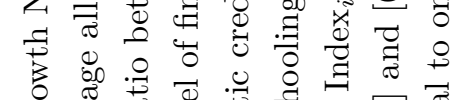

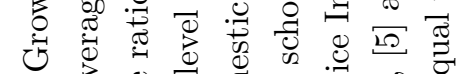

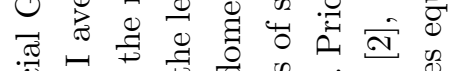

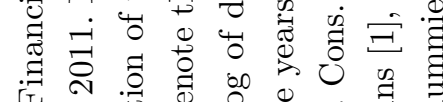
侌

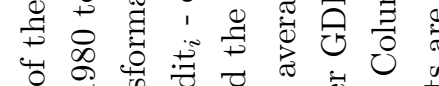

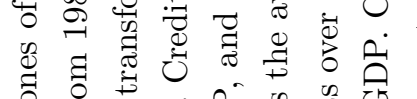

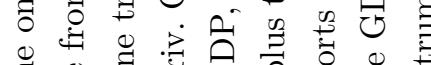

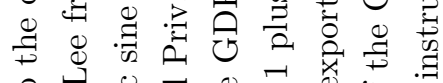
$\circ \begin{aligned} & 0 \\ & 0\end{aligned}$ 苛 当

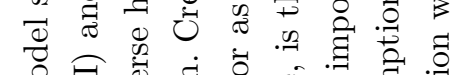

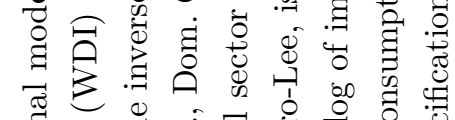

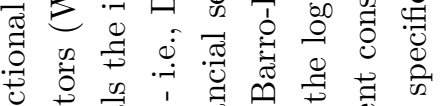
诺 b पै

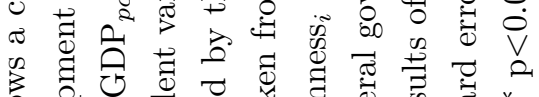

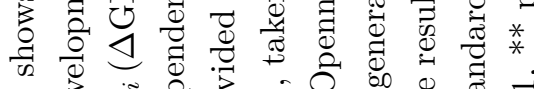

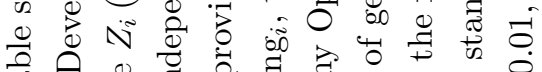

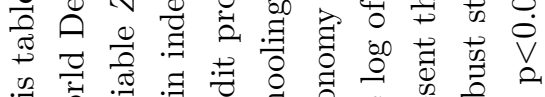

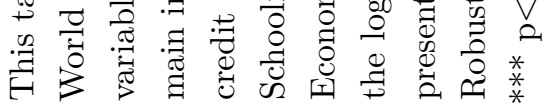




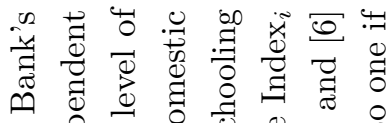

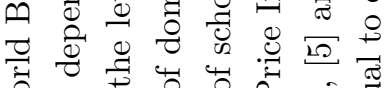

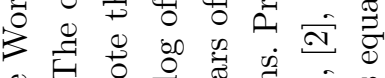

Ð

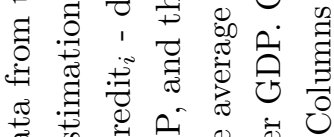

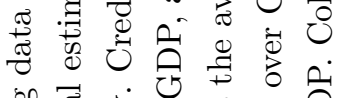

.

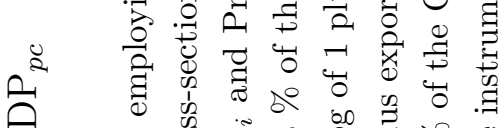

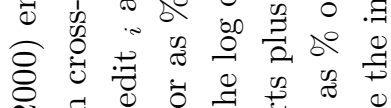

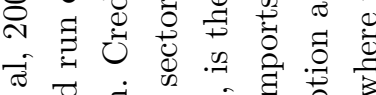

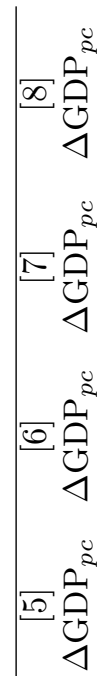

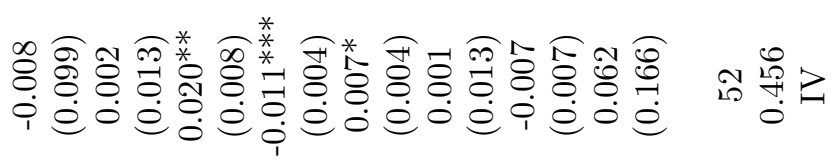

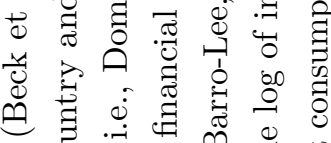
$\underset{0}{0}$

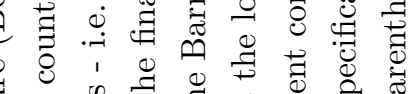

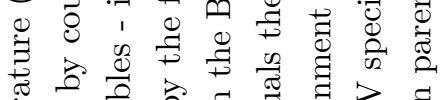

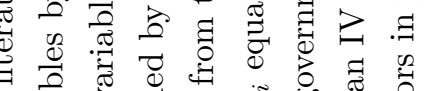

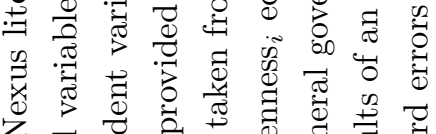

之.

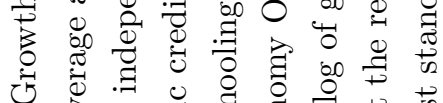

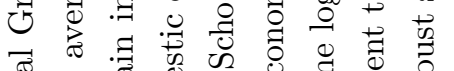

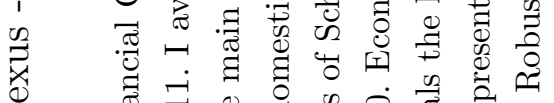

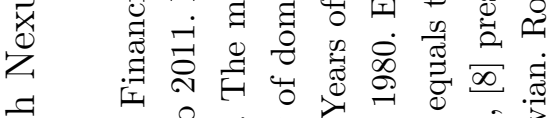

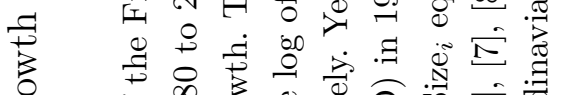

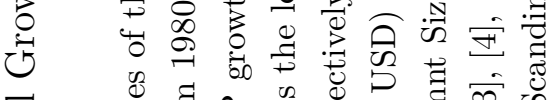

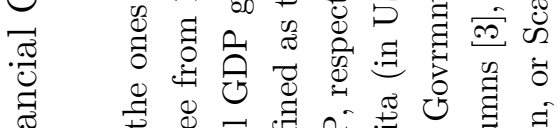

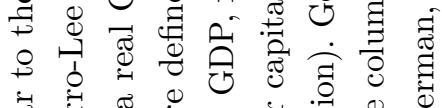

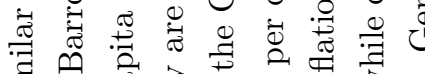

青

苛

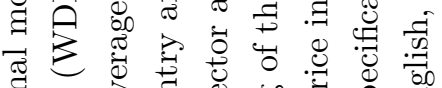

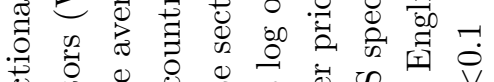

密䓔

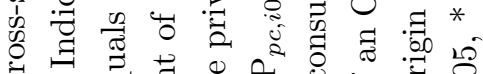

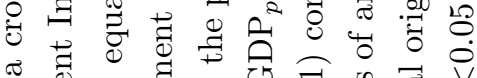

i

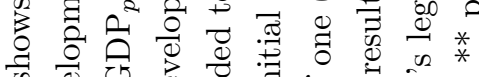

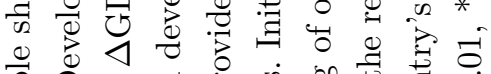

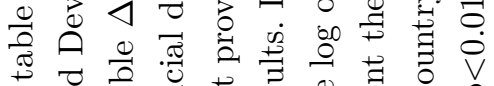

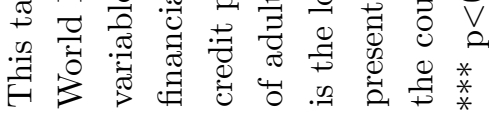

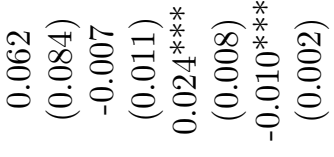

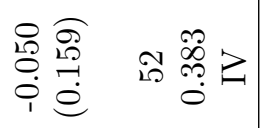

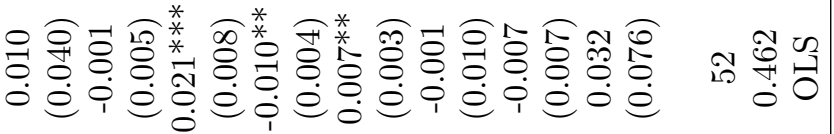

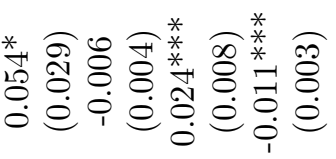

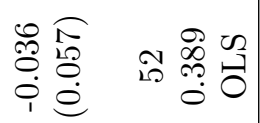

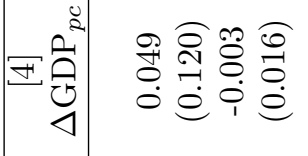

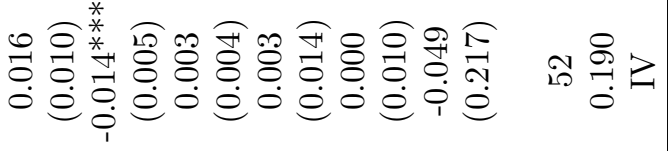

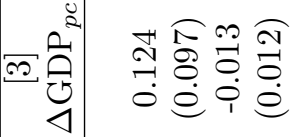

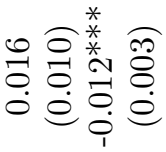

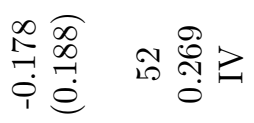

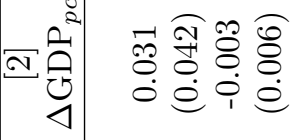

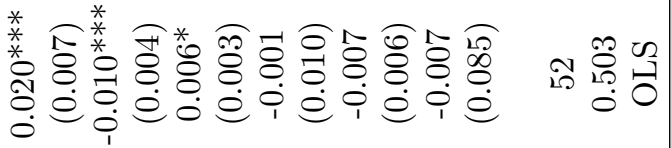

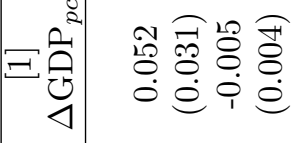

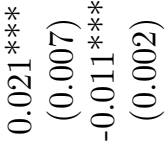

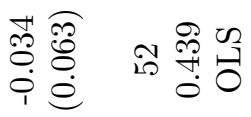

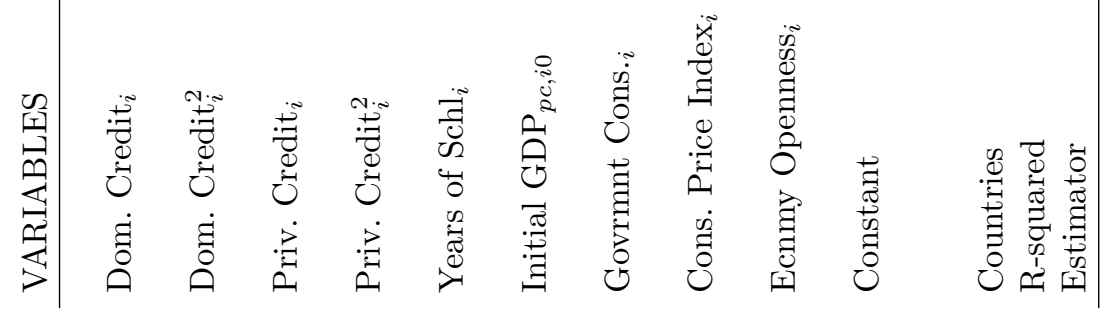




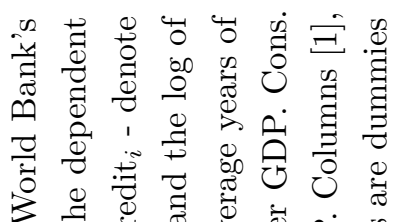
ज记

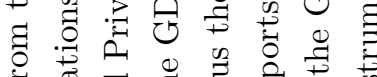

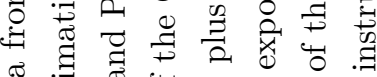

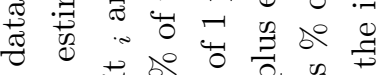

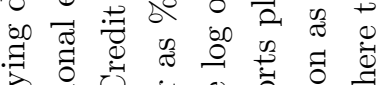

¿

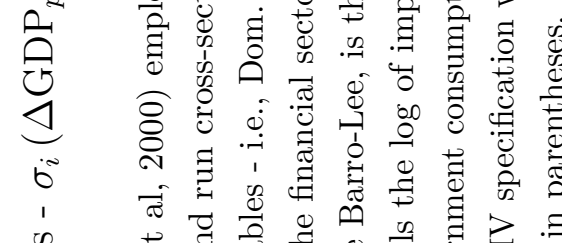

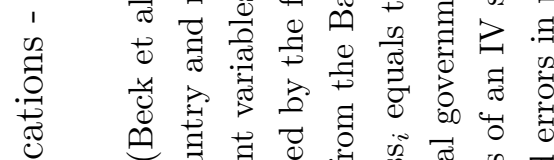

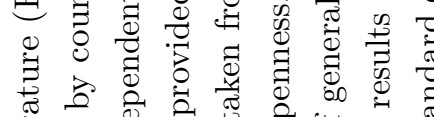

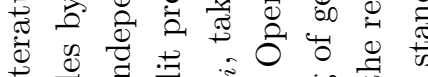

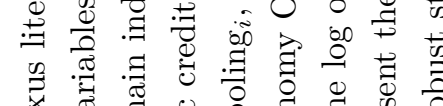

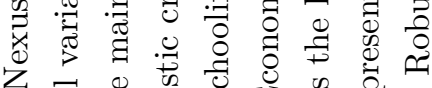
乙

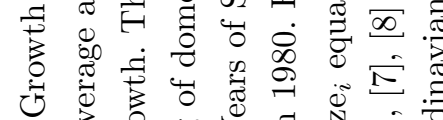
ن 焉 寻穴记 任

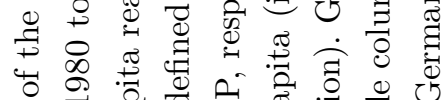
पै छ ○

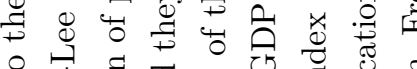
๑

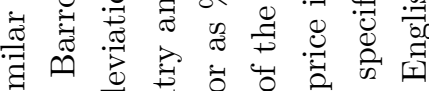
.

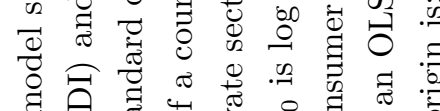

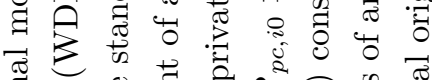

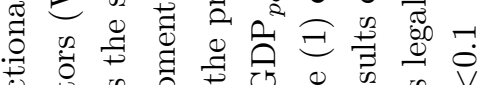

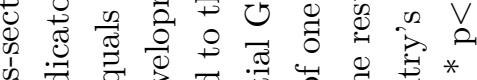
w

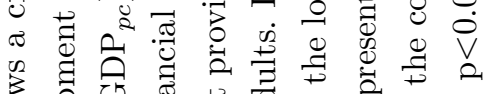

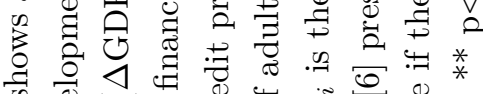
की 苛

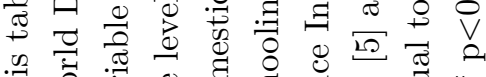

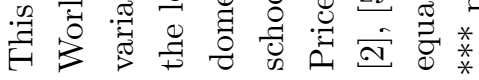


च च च

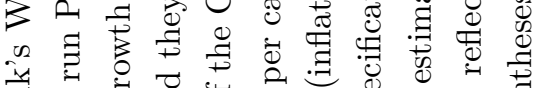

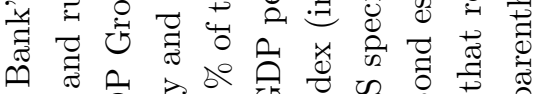

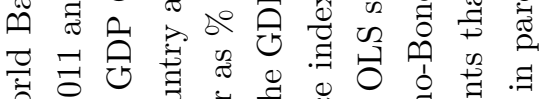

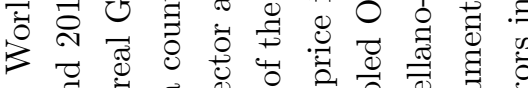

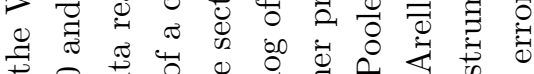

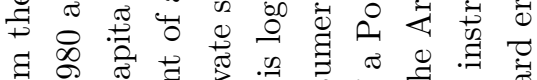
घี

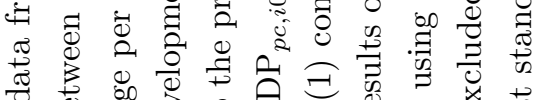

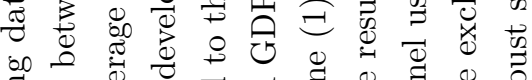

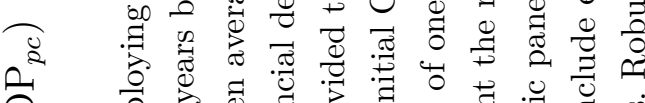

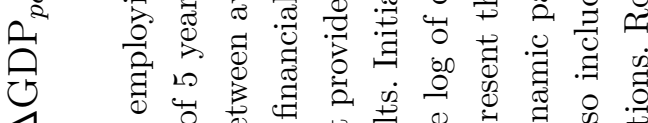
\

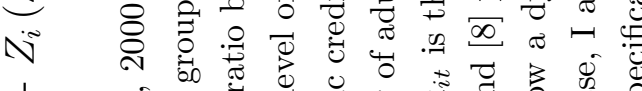
1 क

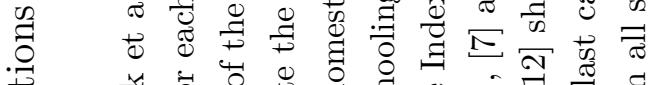

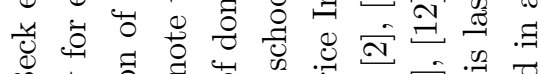

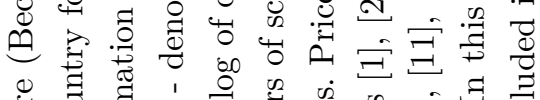

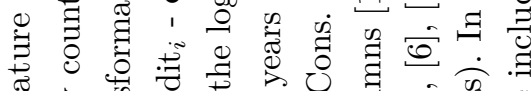

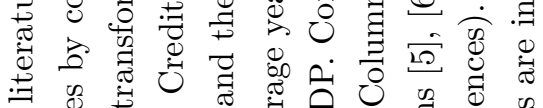

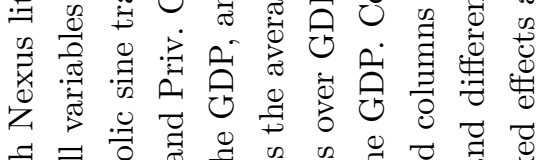

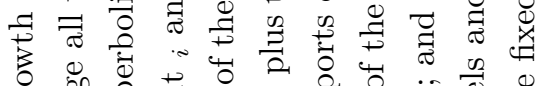

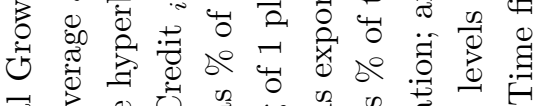

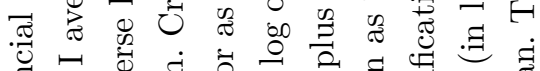

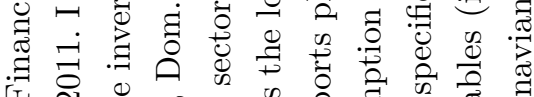

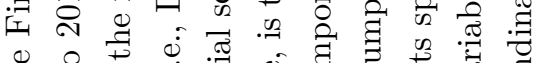

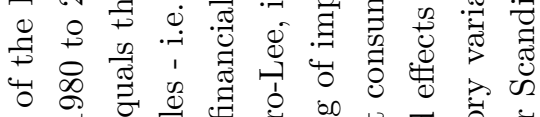

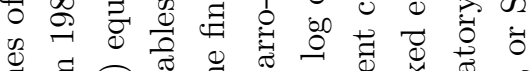

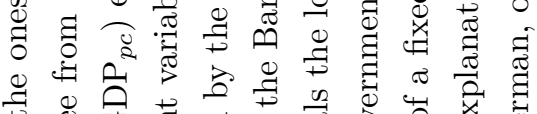

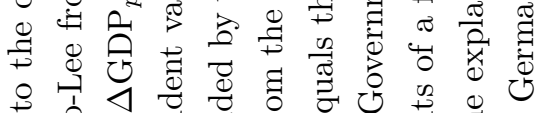

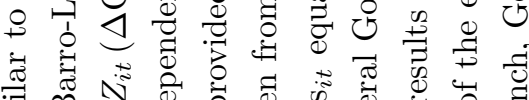

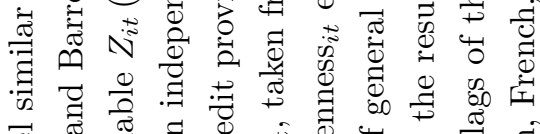
兽

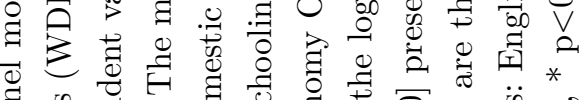

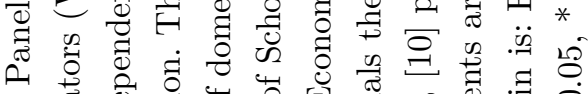

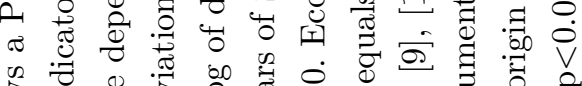

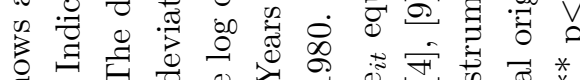

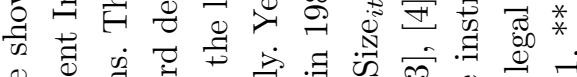

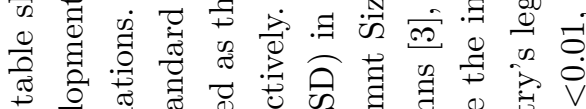

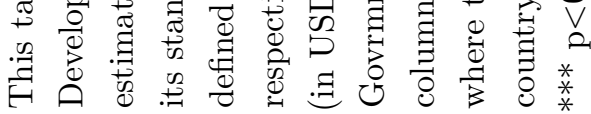

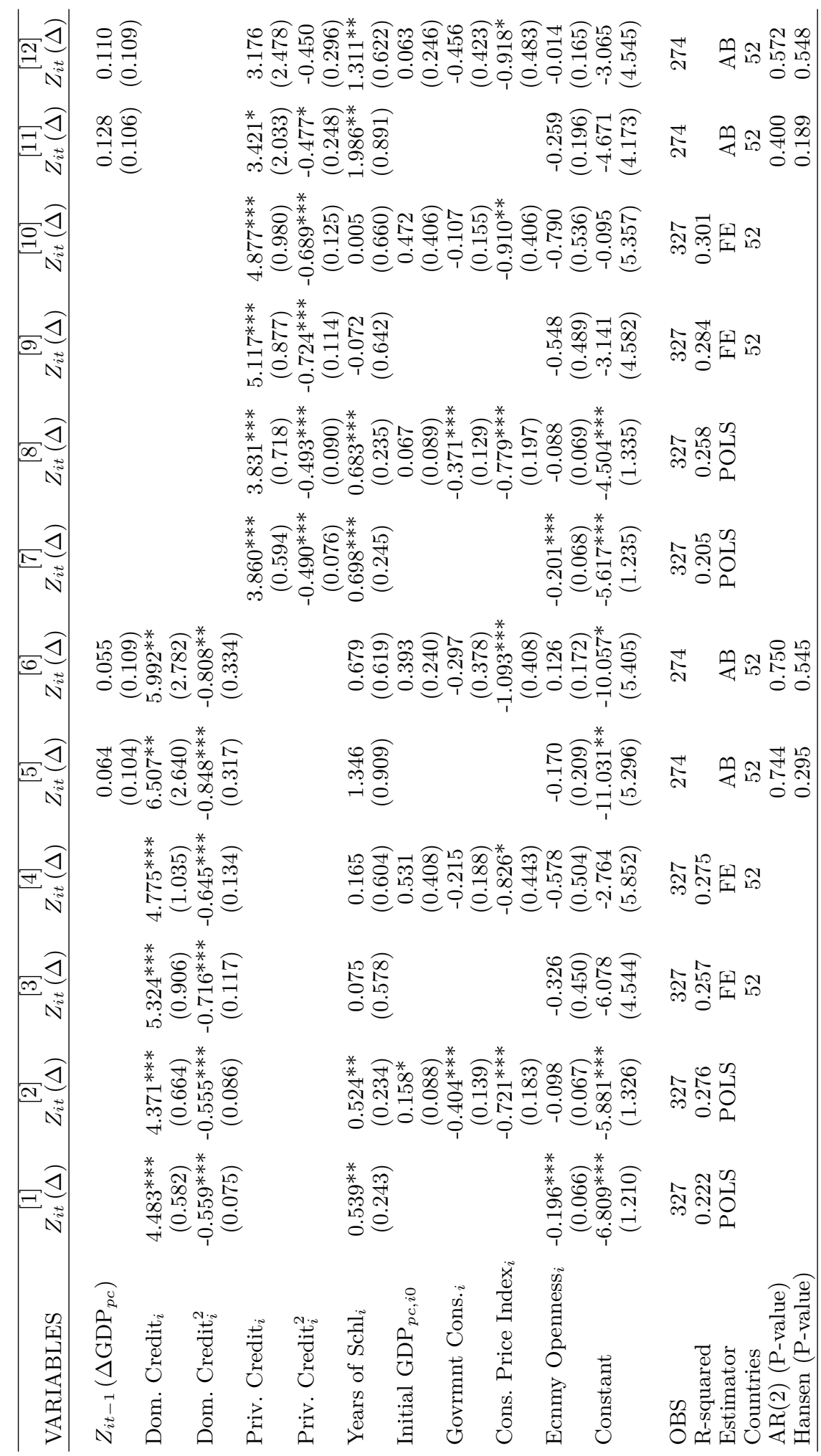




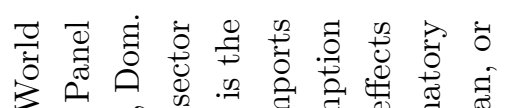

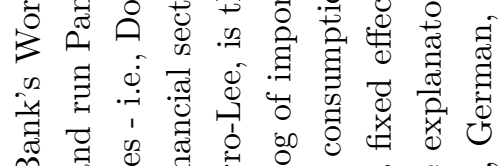

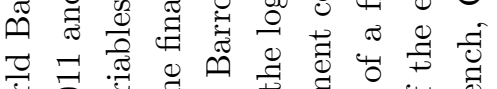

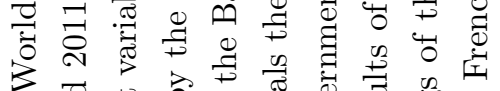

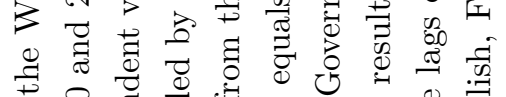

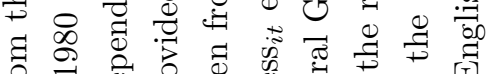

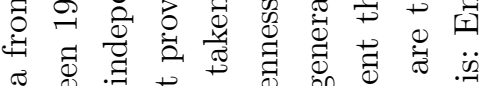

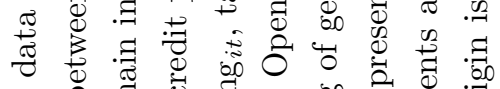

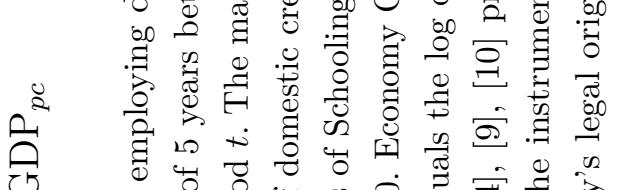

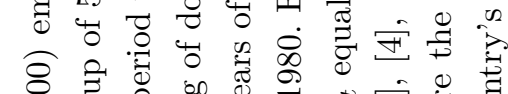

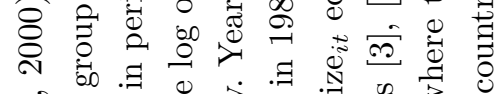

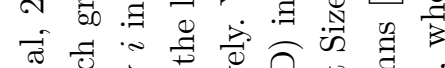

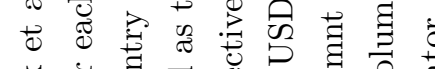

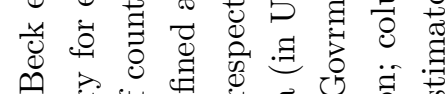
ตำ

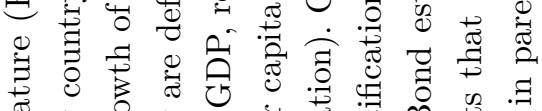

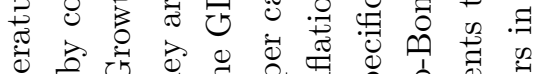

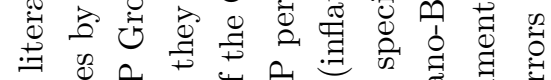

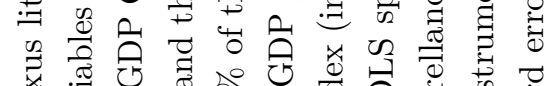

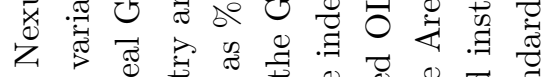

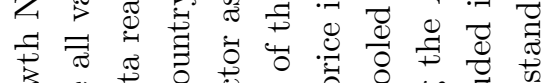

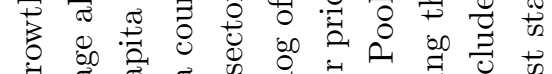

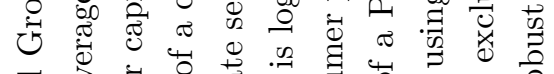

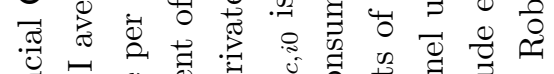

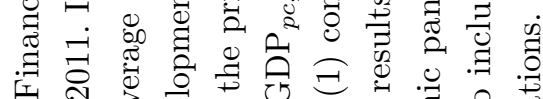

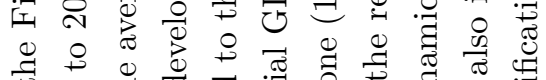

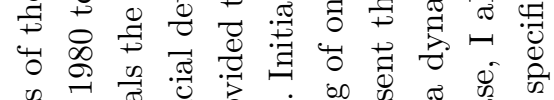
橧 等

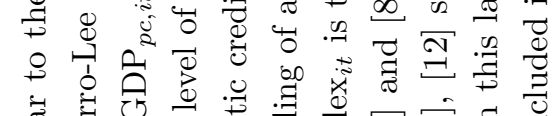

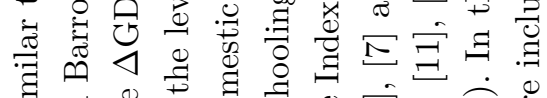
家者

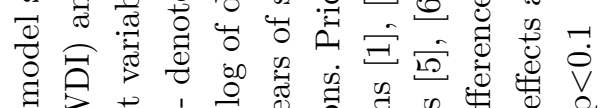

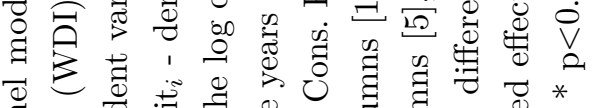

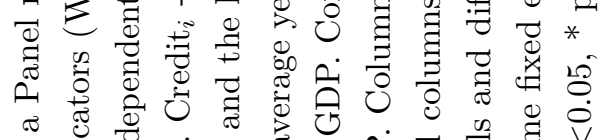

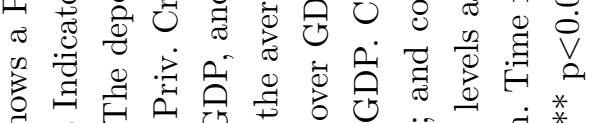
安

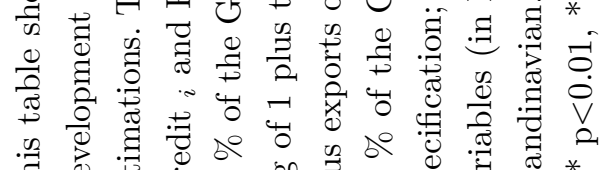

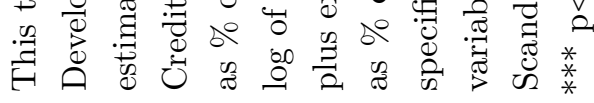

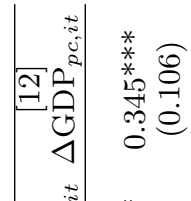

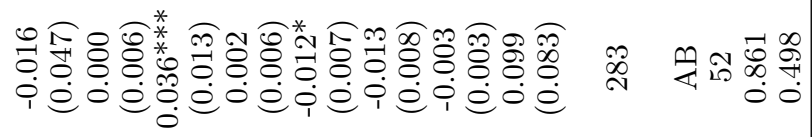

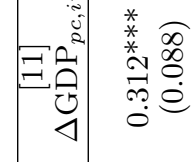

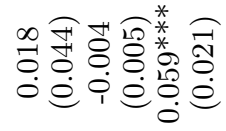

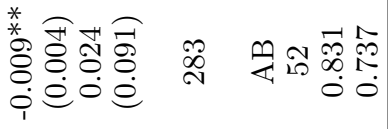
当

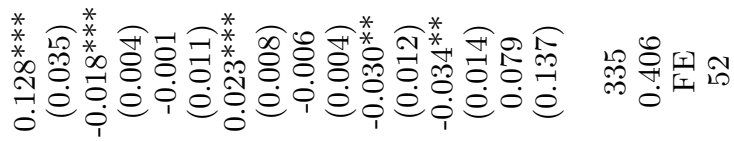

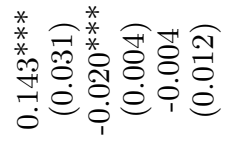

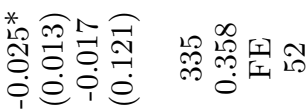

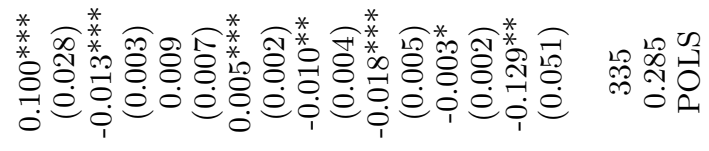

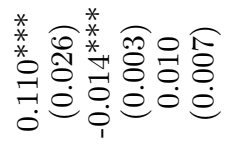

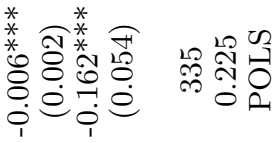

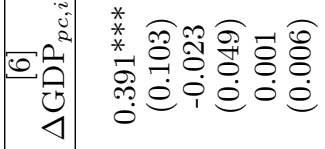

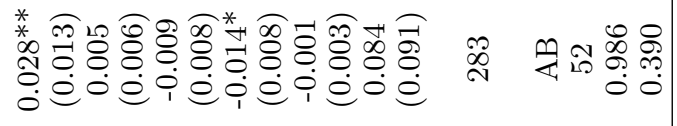

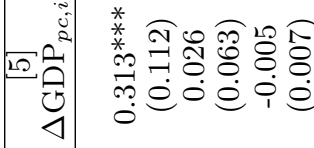

喜高亳

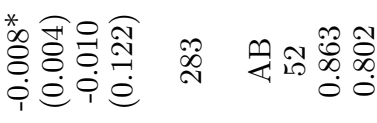

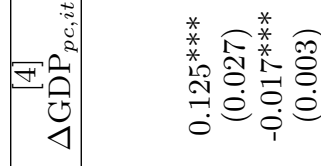

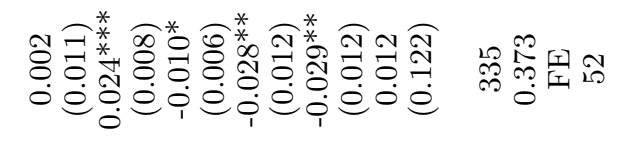

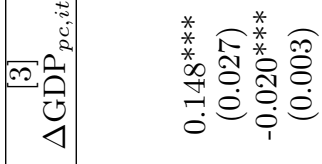

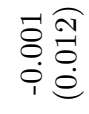

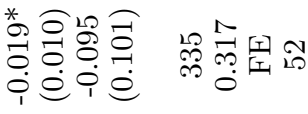

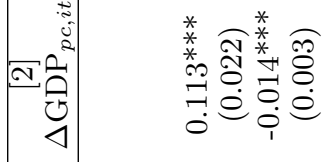

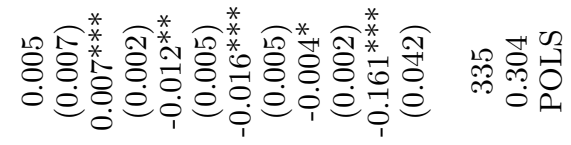

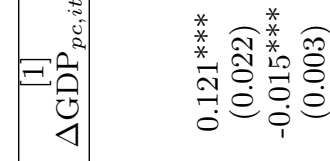

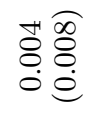

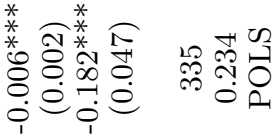

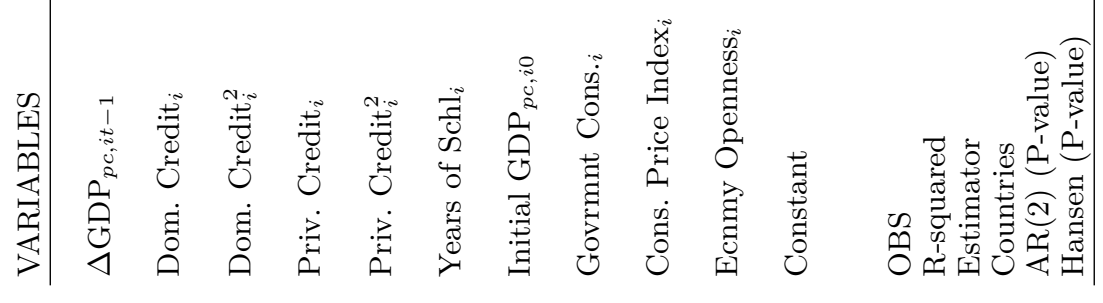




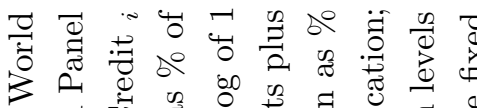

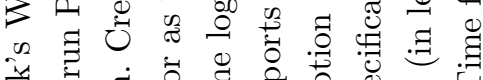

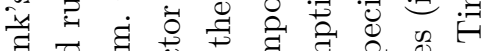
ตี

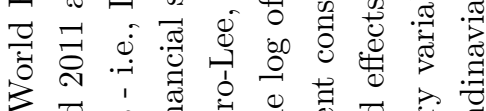

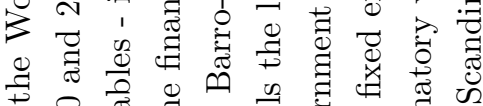
$\Rightarrow$ \&

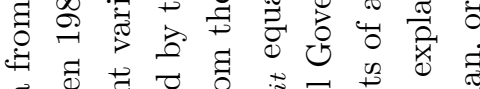

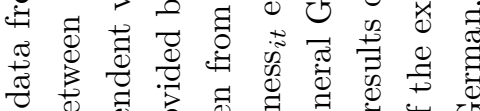

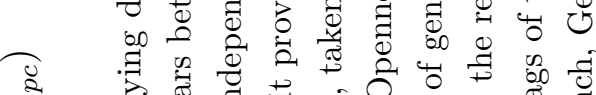

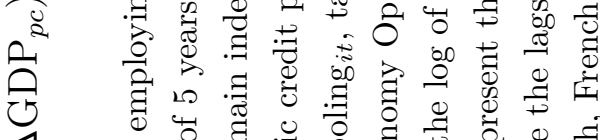

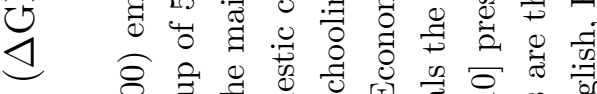

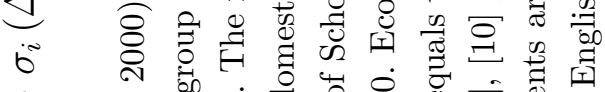

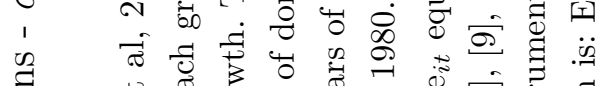

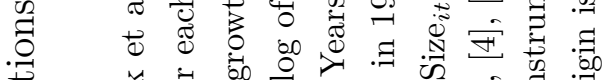
苟苛

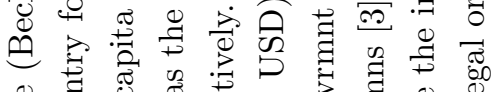

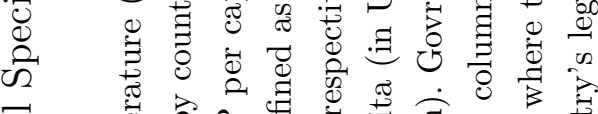

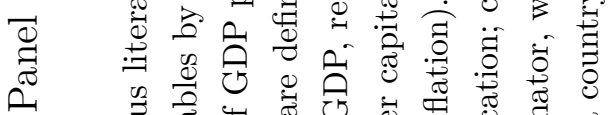

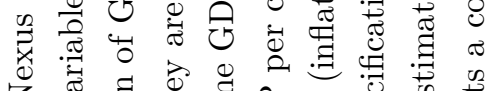
n z

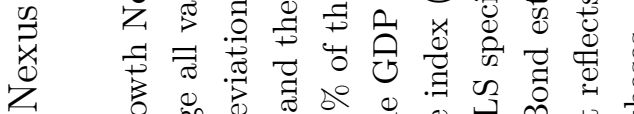

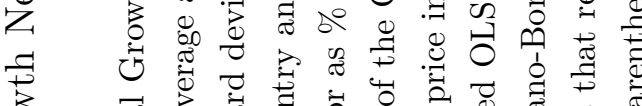

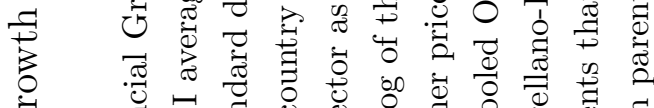
苟

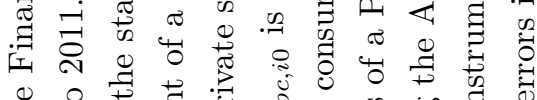

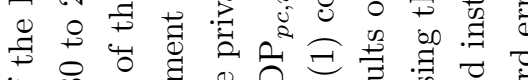

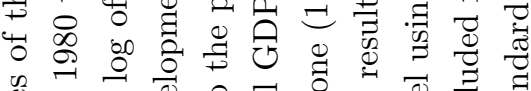

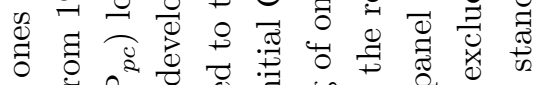

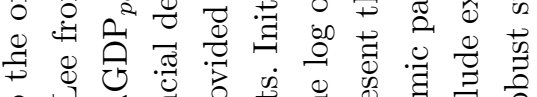

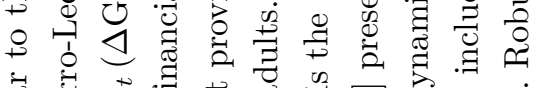

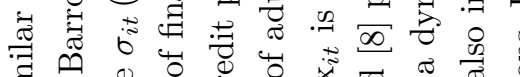

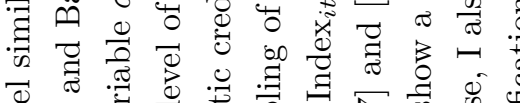

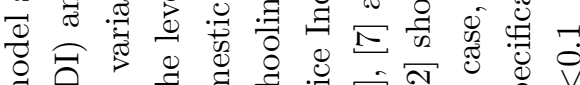

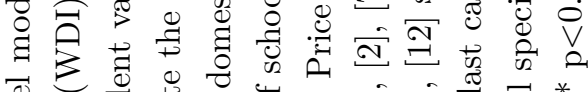

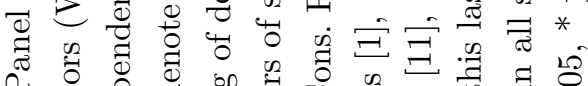

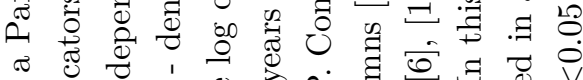

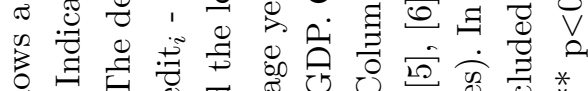

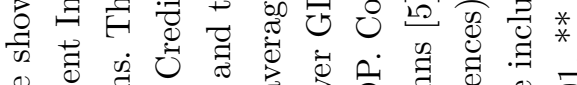

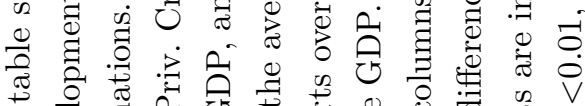

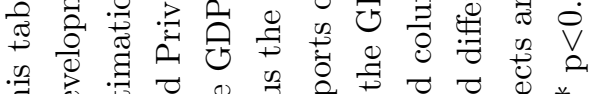

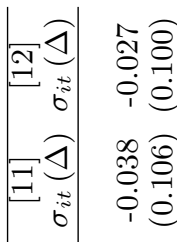

인

$\exists$

$\sigma$

$\infty$

E

0 - 1

Q

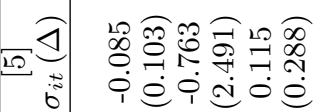

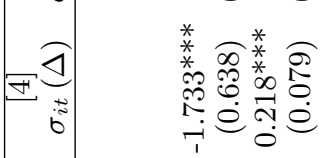

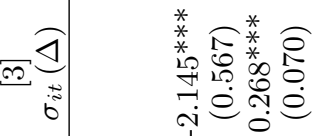

₹ ๙ิ

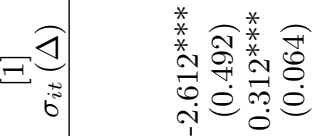

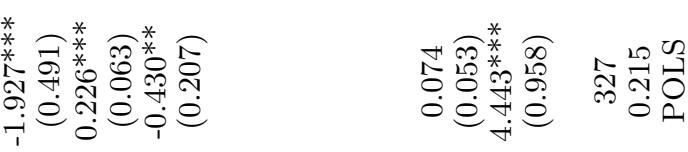

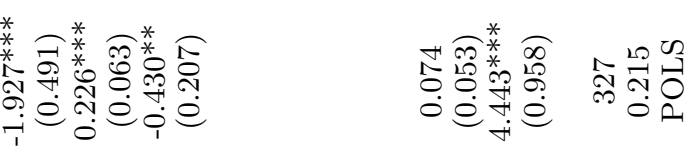

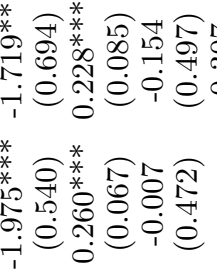

$\begin{array}{llll}* & \\ * \\ *\end{array}$

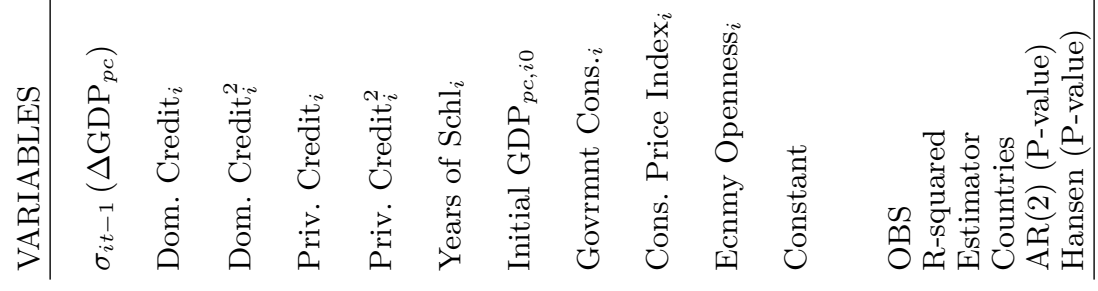





\section{APÊNDICE C - Fontes de dados}

\begin{tabular}{|c|c|c|}
\hline Variable & Variable definition & Source \\
\hline$\Delta \mathrm{GDP}_{p c}$ & GDP per capita growth & World Bank WDI \\
\hline$\sigma_{i}\left(\Delta \mathrm{GDP}_{p c}\right)$ & Log of the standard deviation of GDP per capita growth & Own calculation \\
\hline$Z\left(\Delta \mathrm{GDP}_{p c}\right)$ & $\begin{array}{l}\text { The inverse hyperbolic sine transformation of the average } \\
\text { GDP per capita growth divided by the standard deviation } \\
\text { of GDP per capita growth }\end{array}$ & Own calculation \\
\hline Dom. Credit & $\begin{array}{l}\text { The log of domestic credit to private sector by banks ( } \% \\
\text { of GDP) }\end{array}$ & World Bank WDI \\
\hline Priv. Credit & $\begin{array}{l}\text { The log of private credit by deposit money banks and other } \\
\text { financial institutions to GDP (\% of GDP) }\end{array}$ & World Bank GFDD \\
\hline Ecnmy. Openness & $\begin{array}{l}\text { Log of the sum of Imports and Exports of goods and } \\
\text { services (\% of GDP) }\end{array}$ & World Bank WDI \\
\hline Cons. Price Index & Log of 1 plus inflation, consumer prices & World Bank WDI \\
\hline Years of Schl & $\begin{array}{l}\text { Log of } 1 \text { plus the average year of schooling in the total } \\
\text { population ( } 25 \text { years and over) }\end{array}$ & Barro-Lee \\
\hline Govrmnt. Consumption & $\begin{array}{l}\text { Log of general government final consumption expenditure } \\
\text { (\% of GDP) }\end{array}$ & World Bank WDI \\
\hline Initial $\mathrm{GDP}_{p c, 0}$ & $\begin{array}{l}\text { Log of the GDP per capita from the first year of period. } \\
\text { (2005 prices) }\end{array}$ & World Bank WDI \\
\hline
\end{tabular}

